\title{
Application of Lean Six Sigma Methodologies and In-Vitro Dissolution Studies for Simultaneous Determination of Cefdinir and Sodium Benzoate by RP-HPLC and UPLC Methods in their Dosage Forms
}

\author{
Mohamed EM Hassouna*1 and Mahmoud A Mohamed ${ }^{2}$ \\ ${ }^{1}$ Chemistry Department, Faculty of Science, Beni-Suef University, Egypt \\ ${ }^{2}$ HIKMA group, Pharmaceutical Company, Beni-Suef, Egypt
}

*Corresponding author: Mohamed EM Hassouna, Chemistry Department, Faculty of Science, Beni-Suef University, Egypt

\section{ARTICLE INFO}

Received: March 30, 2019

Published: April 03, 2019

Citation: Mohamed EM Hassouna, Mahmoud A Mohamed. Application of Lean Six Sigma Methodologies and In-Vitro Dissolution Studies for Simultaneous Determination of Cefdinir and Sodium Benzoate by RP-HPLC and UPLC Methods in their Dosage Forms. Biomed J Sci \& Tech Res 16(5)-2019. BJSTR. MS.ID.002901.

Abbreviations: POS: Powder for Oral Suspension; CAP: Capsule; CFR: Cefdinir; USP: United States Pharmacopeia; HPLC: High Performance Liquid Chromatography; BP: British Pharmacopeia; TLC: Thin Layer Chromatography; UPLC: Ultra Performance Liquid Chromatography

\section{ABSTRACT}

Application of Lean Six Sigma and Quality tools plays an important role in interpretation of the data of quality attributes, decreasing waste time, remission manpower and reducing variation which will give intensity, confidence, and thoroughness. Thus, one can follow up and assure that the Process Capability Index (Cpk) is $>1.33$ and still capable during the all stages of the product. The purposes of this work are: to develop and validate a simple, accurate, precise and new RP-HPLC and UPLC methods, after reconstitution, accelerated stability and comparative in vitro dissolution studies. These were proceeded for the simultaneous determination of cefdinir (CFR) and sodium benzoate (SDM), respectively in the generic product; Dinar $125 \mathrm{mg} / 5 \mathrm{~mL}$ powder for oral suspension (POS) and Dinar $300 \mathrm{mg}$ capsule (CAP) and consequently it had been considered equivalent to the innovator product; Omnicef $125 \mathrm{mg} / 5 \mathrm{~mL}$ POS and Omnicef $300 \mathrm{mg}$ CAP using FDA media of $0.05 \mathrm{M}$ phosphate buffer having $\mathrm{pH}$ 6.8. The chromatographic separation and resolution were performed at ambient temperature using:

a) Agilent Eclipse XDB C8 column (250 mm X $4.6 \mathrm{~mm}, 5 \mu \mathrm{m}$ particle size) with a mobile phase consisting of acetonitrile: $0.05 \mathrm{M}$ phosphate buffer solution $\mathrm{pH}$ 4.5 (50:50 $\mathrm{v} / \mathrm{v}$ ) at flow rate of $1.0 \mathrm{~mL} /$ minute, injection volume $10 \mu \mathrm{L}$ for RP-HPLC.

b) Waters CORTECS ${ }^{\circledR}$ C18 column (50 mm X $4.6 \mathrm{~mm}, 2.7 \mu \mathrm{m}$ particle size) at flow rate $0.3 \mathrm{~mL} / \mathrm{min}$ and injection volume $0.3 \mu \mathrm{L}$ for RP-UPLC. UV detection at $254 \mathrm{~nm}$ was used with correlation coefficients $(r)>0.999$ for CFR and SDM, respectively. The method was validated according to ICH guidelines.

Keywords: Cefdinir; Sodium Benzoate; Lean Six Sigma; In vitro dissolution; RP- HPLC and UPLC

\section{Introduction}

Recently, the use of application of quality tools and lean six sigma methodologies are widespread in most of the industries, especially pharmaceutical industries that are intended to reduce waste time, eliminate defects in the process and increase the capability of the process [1]. Simultaneous determination of binary mixture analytes in one reaction system using the same reagent and columns has become fascinating feature and very useful in modern analytical chemistry. This leads to saving money and effort of analysts as well as it is beneficial for quality control laboratory to analysis and release batch of product before the deadline. So, the current work introduces a new RP-HPLC and UPLC methods for simultaneous quantification of cefdinir and sodium benzoate in their pure and dosage forms, application of lean six sigma methodologies and in vitro dissolution studies to compare among different suppliers and 
manufacturers. Cefdinir (CFR) (Figure 1a) is a third-generation oral cephalosporin antibiotic sold under the brand names Cefzon and Omnicef. It is chemically named as [6R- [6 $\alpha, 7 \beta(\mathrm{Z})]]-7-[[(2-a m i n o-$ 4thiazolyl) (hydroxyimino)acetyl] amino]-3-ethenyl-8-oxo-5-thia1-azabicyclo [4.2.0] oct-2-ene2-carboxylic acid.

Cefdinir is a white to slightly brownish-yellow solid. It is slightly soluble in dilute hydrochloric acid and sparingly soluble in $0.1 \mathrm{M}$ pH 7.0 phosphate buffer. The empirical formula is $\mathrm{C}_{14} \mathrm{H}_{13} \mathrm{~N}_{5} \mathrm{O}_{5} \mathrm{~S}_{2}$ and the molecular weight is 395.42 [2]. CFR belongs to a class of antibiotics called cephalosporins, which work for killing bacteria or halting their growth. CFR is prescribed to treat a wide range of bacterial infections, including certain types of pneumonia, sinusitis, bronchitis, strep throat, sore throat, middle-ear infections, and certain skin infections [2]. SDM is the chemical benzoate of soda $\left(\mathrm{C}_{7} \mathrm{H}_{5} \mathrm{NaO}_{2}\right)$ (Figure $1 \mathrm{~b}$ ), produced by the neutralization of benzoic acid with sodium bicarbonate, sodium carbonate, or sodium hydroxide. The salt doesn't occur naturally. The ingredient is used as an antimicrobial and as a flavoring agent used in food at levels not to exceed good manufacturing practice. Current usage results in a maximum level of 0.1 percent in food [3]. An HPLC method for determination of CFR is officially reported in the United States Pharmacopeia (USP) [4].

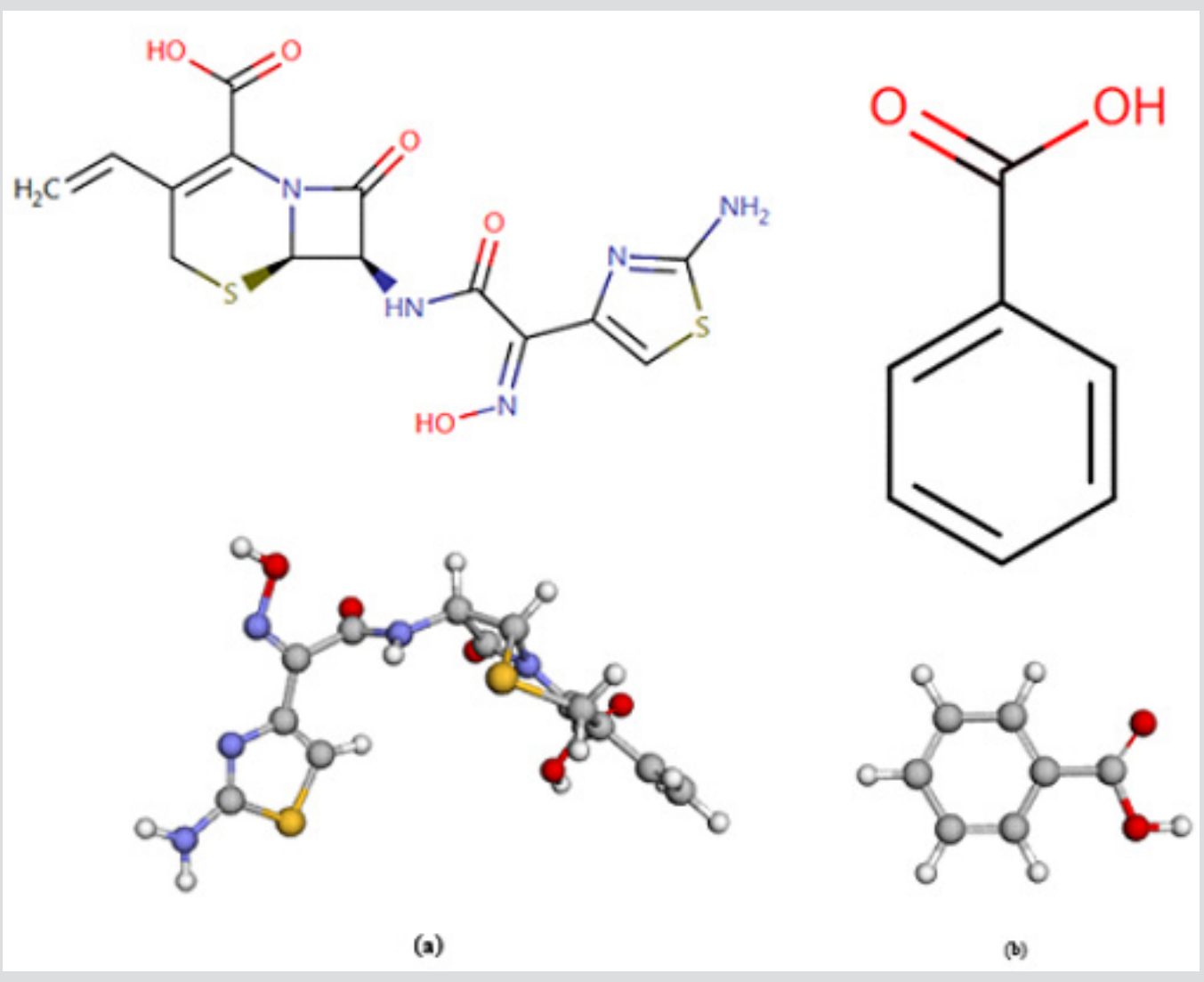

Figure 1: Chemical structures of (a) Cefdinir and (b) Sodium benzoate.

It is still a limited number of analytical methods that are reported for the determination of CFR individually or in combination with other drugs including High performance liquid chromatography (HPLC) [5-12], Ultra performance liquid chromatography (UPLC) [13], capillary electrophoresis and electrochemical methods $[14,15]$, thin layer chromatography (TLC) [16], colorimetric and spectrophotometric [17-21], and comparative in vitro dissolution studies for cephalosporins [22,23]. Like CFR, SDM is officially reported in British Pharmacopeia (BP) [24] and United States Pharmacopeia (USP) including titration and HPLC. The literature review revealed that a variety of analytical methods have been reported for its determination in its pure drug and dosage forms using HPLC [25-27], Ultra performance liquid chromatography (UPLC) $[28,29]$, HPTLC [30], Isoabsorption [31], and spectrophotometry
$[32,33]$. For the best of our knowledge, there is no RP-HPLC and UPLC methods for the simultaneous determination of cefdinir and sodium benzoate in their pure, powder for oral suspension and capsule dosage forms without previous separation. Therefore, the main aim of this work is to establish this needed novel RP-HPLC and UPLC methods for the determination of binary mixture of CFR and SDM and application of lean six sigma methodologies, quality tools and comparative in vitro dissolution studies.

\section{Experimental}

\section{Apparatus}

Waters ACQUITY ${ }^{\circledR}$ Arc $^{\mathrm{TM}}$ UPLC System, a quaternary liquid chromatography provides plug-and-play method compatibility 
for UPLC separations with 2489 UV/Vis Detector with Empower ${ }^{\mathrm{TM}}$ 3 Software. UV- 1800 double beam UV-Visible spectrophotometer (shimadzu-Japan) with the highest resolution and spectral bandwidth of (1nm from 190-1100 nm range) matched with $1 \mathrm{~cm}$ quartz cells, was used for all absorbance measurements. Perform data analysis by software (UV-Probe 2.5.2). Dissolution apparatus (PTWS 1220, Pharma Test Apparatebau AG, Germany) is used to study the dissolution profile. Climatic chamber (VOSTCH VP 1300, Germany) with SIMPATI 4.06 Software is qualified and calibrated under storage condition $\left(40 \pm 2^{\circ} \mathrm{C} / 75 \pm 5 \% \mathrm{RH}\right)$. pH meter METTLER TOLEDO Seven Compact. Statistical analysis was performed using Minitab $^{\circledR}$ 17.1.0 and validated Microsoft Excel sheet 2016 .

\section{Pure Samples}

CFR API Corporation (Japan), covalent lab (India) and SDM were kindly supplied by Hikma pharmaceutical industries company, BeniSuef, Egypt with potency of 99.7\%, 98.8\% and 99.9\%, respectively.

\section{Pharmaceutical Formulations}

Innovator Product Omnicef $125 \mathrm{mg}$ per $5 \mathrm{~mL}$ POS and Omnicef 300 mg CAP are supplied by Hikma Pharmaceuticals which gained a license of Omnicef from Astellas Pharma (Japan). Generic product DINAR $125 \mathrm{mg}$ per $5 \mathrm{~mL}$ POS and DINAR $300 \mathrm{mg}$ CAP are purchased from Adweia company.

\section{Reagents}

Acetonitrile HPLC-grade, methanol HPLC-grade, purified water, potassium dihydrogen orthophosphate, sodium hydroxide, hydrochloric acid, hydrogen peroxide and orthophosphoric acid analytical grade, are procured from (Scharlau, Spain).

\section{Solvent}

Dissolve about 3.4gm potassium dihydrogen phosphate and $10.65 \mathrm{gm}$ disodium hydrogen phosphate in about $750 \mathrm{~mL}$ water. Adjust the pH to $7.0 \pm 0.05$ using phosphoric acid or $1 \mathrm{~N} \mathrm{NaOH}$ solution then add sufficient water to make $1000 \mathrm{~mL}$.

\section{Standard Solutions}

\section{Stock Standard Solution $(1500 \mu \mathrm{g} / \mathrm{mL}$ of CFR and $1000 \mu \mathrm{g} / \mathrm{mL}$} SDM)

Accurately transfer $150 \mathrm{mg}$ of CFR and $100 \mathrm{mg}$ of CFR into 100 $\mathrm{mL}$ volumetric flask. Add about $70 \mathrm{~mL}$ of solvent. Sonicate for 10 min till dissolving then completes to volume with the same solvent and mix well.

\section{Laboratory Prepared Mixture $(250 \mu \mathrm{g} / \mathrm{mL})$ of each of CFR and SDM}

Due to the low concentration of SDM in the sample where CFR is twenty-five folds higher than SDM, so we have prepared a mixture of equal concentrations $(250 \mu \mathrm{g} / \mathrm{mL})$ of each of CFR and SDM using solvent as a blank to show the peak shape and to assure the separation quality (Figure 2a).

\section{Working Standard Solution (750 $\mu \mathrm{g} / \mathrm{mL})$ of CFR and (30 $\mu \mathrm{g}$ / mL) SDM}

Accurately transfer $5 \mathrm{~mL}$ and $3 \mathrm{~mL}$ aliquot from each of the previously prepared stock standard solutions into $10-\mathrm{mL}$ volumetric flasks. Complete to volume with the same solvent. Mix well and filter through $0.45 \mu \mathrm{m}$ Nylon filter and inject into the chromatographic system (Figure 2 b \& 2c).
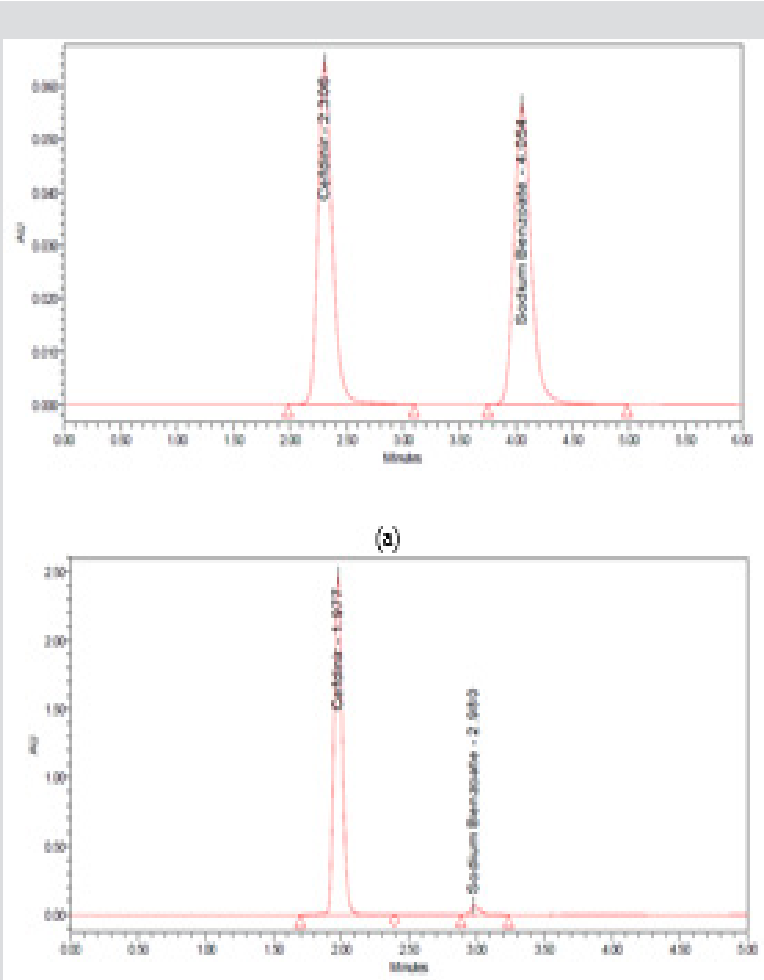

(b)

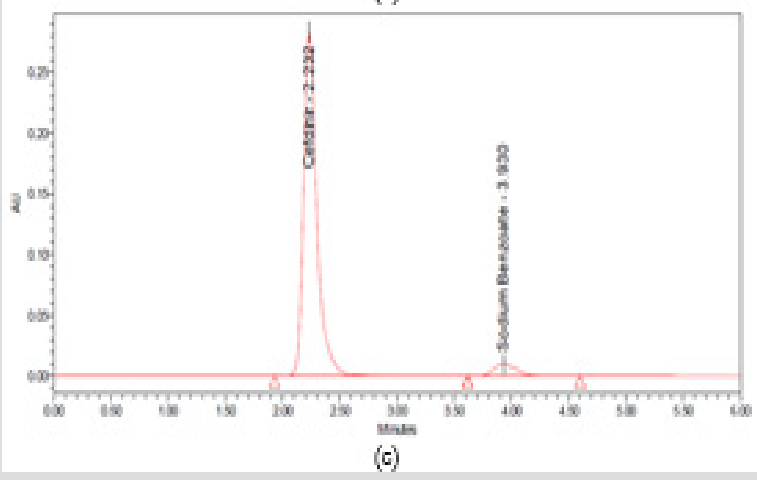

Figure 2: chromatograms of (a) $250 \mu \mathrm{g} / \mathrm{mL}$ of CFR and SDM and $750: 30 \mu \mathrm{g} / \mathrm{mL}$ of a mixture of CFR and SDM at (b) HPLC (c) UPLC.

\section{Application to Pharmaceutical Formulation (Omnicef $®$ and DINAR ${ }^{8} 125 \mathrm{mg} / 5 \mathrm{~mL}$ POS)}

Tabbing bottle to loosen powder, add water in two portions, shaking well after each addition, complete to the mark with water. Directly transfer from the bottle $3 \mathrm{~mL}$ (equivalent to $75 \mathrm{mg}$ CFR 
and $3.0 \mathrm{mg}$ SDM) into a $100-\mathrm{mL}$ volumetric flask, add about $75 \mathrm{~mL}$ solvent, sonicate for $10 \mathrm{~min}$ till dissolved then complete to volume with the same solvent. Mix well and filter through $0.45 \mu \mathrm{m}$ Nylon filter and inject into the chromatographic system.

\section{Application to Pharmaceutical Formulation (Omnicef $₫$ and DINAR $® 300$ mg CAP)}

Weigh and empty 20 capsules and calculate the average content per capsule. Weigh accurately about the equivalent to $150 \mathrm{mg}$ CFR from their contents. Then transfer completely to $200 \mathrm{~mL}$ volumetric flask with the aid of $150 \mathrm{~mL}$ solvent, sonicate for about 10 minutes and complete to volume with the same solvent and mix well. Filter through $0.45 \mu \mathrm{m}$ Nylon filter and inject into the chromatographic system.

\section{Chromatographic Conditions}

Isocratic separation was performed at ambient temperature using Agilent XDB-C8 (4.6 mm x $250 \mathrm{~mm}$ ) $5 \mu \mathrm{m}$ or equivalent, with a mobile phase consisting of acetonitrile: $0.05 \mathrm{M}$ phosphate buffer solution $\mathrm{pH} 4.5(50: 50 \mathrm{v} / \mathrm{v})$ at flow rate of $1.0 \mathrm{~mL} /$ minute and UV detection at $254 \mathrm{~nm}$ with injection volume of $10 \mu \mathrm{L}$ for RP-HPLC. Waters CORTECS ${ }^{\circledR} \mathrm{C} 18$ column $(50 \mathrm{~mm} \times 4.6 \mathrm{~mm}, 2.7 \mu \mathrm{m}$ particle size) at flow rate $0.3 \mathrm{~mL} / \mathrm{min}$, injection volume $0.3 \mu \mathrm{L}$ was used for RP-UPLC where the total run time was 6 min.

\section{Construction of Calibration Curves}

Separately transfer different dilutions from their corresponding stock standard solutions into separate series of $10 \mathrm{~mL}$ volumetric flasks covering the concentration ranges $(50-1000 \mu \mathrm{g} / \mathrm{mL})$ of CFR and (5-50 $\mu \mathrm{g} / \mathrm{mL})$ of SDM. Triplicate 10 and $0.3 \mu \mathrm{L}$ injections were injected for each concentration applying the recommended chromatographic conditions. The chromatograms were recorded, the peak areas of both CFR \& SDM were estimated and the calibration curves relating the obtained integrated peak areas to the corresponding concentrations were constructed and the regression equations were computed.

\section{Comparative in Vitro Dissolution Study}

The main reason for making comparative in vitro dissolution study is to disclose any variation occurring in the final product market as change in inactive ingredients, change in raw material suppliers (as adding new supplier) or submission re-registration stability file product for ministry of health $(\mathrm{MOH})$, so in the previous cases comparative in vitro dissolution study must be performed to release the drug products.

\section{Dissolution Parameters}

Apparatus: Type II (Paddle)

Dissolution medium volume: 0.05 M Phosphate buffer, pH 6.8

Speed: $50 \mathrm{rpm}$

Temperature: $37 \pm 0.5^{\circ} \mathrm{C}$

Time: 10,20,30 and 45 minutes

\section{Test Preparation}

Place one unit in each vessel from the generic product and the innovator one, using sinker in case of capsule and immediately operate the apparatus at the rate specified. The automated system will withdraw the samples at time intervals, then drug release was measured using the chromatographic system.

\section{After Reconstitution Studies and Accelerated Stability}

Re-constitution stability study was conducted on the first new supplier batch under storage condition $5 \pm 3^{\circ} \mathrm{C}$ in refrigerator for 14 days to provide information for the labelling on the preparation, storage condition, and in-use period of the constituted or diluted product. Accelerated stability studies intended to increase the rate of physical change or chemical degradation by using extravagant conditions of elevated temperature and humidity with the purpose of investigation degradation pathways and predicting shelf life were performed. These cases were tested: storage condition $(40 \pm 20 \mathrm{C}$ / $75 \pm 5 \% \mathrm{RH}$ ) for six months; the first three primary validation batches, if reprocessing occurs in any batch, for post approval manufacturing changes batches, exceeding hold time limitation: If the batch exceeds the time allowed in any manufacturing stage and adding new suppliers [34].

\section{Process Capability Six-pack Quality Tools for Normally Distributed Assay}

Lean six sigma and quality tools play an important role regarding assessing and estimating change during the process, and thus can be useful, also to choose or modify the process in some of the stages of the product improvement, where current work is used to analyse the ability of comparison among various suppliers and follow-up the process during the past two years and assure that the Process Capability Index (Cpk) is $>1.33$.

\section{Results and Discussion}

The present work discusses comparative in vitro dissolution studies for simultaneous determination of the co-formulated binary mixtures of CFR and SDM in their suspension and capsule dosage forms which will lead to a paradigm shift towards pharmaceutical analysis where it reduces wasted time, effort, reagents, and columns. Also, application of lean six sigma and quality tools will help the quality team to detect the defect and variation during the process, so that they can be eliminated easily before the end of the process. Several trials were developed to optimize affecting parameters and to obtain a good separation of the binary mixture of CFR and SDM. So different compositions of mobile phases with different ratios were tried such as methanol (100\%); methanol: purified water $(70: 30, \mathrm{v} / \mathrm{v})$; acetonitrile: purified water $(70: 30, \mathrm{v} / \mathrm{v})$ and methanol: purified water $(95: 5, \mathrm{v} / \mathrm{v})$. All solvents of the mobile phase were filtered through $0.45 \mu \mathrm{m}$ Nylon filter paper to remove particulate matter and degassed by sonication. Also, $(0.2,0.3,0.8$, 1.0, 1.5 and $2.0 \mathrm{~mL} / \mathrm{min}$ ) flow rates were tried. Preliminary studies have been involved trying C8, C18 reversed-phase columns. The best developing mobile phase of the system was found to be a mixture of acetonitrile: $0.05 \mathrm{M}$ phosphate buffer solution $\mathrm{pH} 4.5$ (50:50 v/v) 
at flow rate 1.0 and $0.3 \mathrm{~mL} /$ minute for HPLC and UPLC methods. The retention times are quite short and sufficiently separated. This selected developing system has allowed good separation with good Rt values without tailing of the separated bands and good theoretical plates and resolution.

Wavelengths were scanned at (200 - $400 \mathrm{~nm}$ ) for $15 \mu \mathrm{g} / \mathrm{mL}$ for both drugs, CFR and SDM in pure form (Figure 3), showing maximum absorbance at $283 \mathrm{~nm}$ and $222 \mathrm{~nm}$, respectively. Besides, $\lambda$ max for both drugs are 234 and $208 \mathrm{~nm}$ which are the intersection points of both drugs; were also tested. However, the wavelength $254 \mathrm{~nm}$ was selected for the separation of both drugs because it has maximum intensity and sensitivity. In vitro dissolution studies are considered as a major part of the pharmaceutical industry and regulatory agencies of powder for oral suspensions and capsule dosage forms for comparison of the release rate of the drug products and to demonstrate the quality of in vitro similarity [35]. The acceptance criteria of the dissolution for product release were estimated according to international guidelines and USP monograph comparison. In vitro dissolution profiles of drugs were recommended on three different dissolution mediums $\mathrm{C} \mathrm{pH}$ 1-7.5) In case of the monograph is not available [36]. The best developing system was $900 \mathrm{~mL} 0.05 \mathrm{M}$ phosphate buffer, $\mathrm{pH} 6.8$ Type II (paddle) at speed rate of $50 \mathrm{rpm}$ with time intervals; 10,
20, 30 and 45 minutes. In the present study, the percentage of drug released for dissolution media were $>80 \%$ in $10 \mathrm{~min}$. According to the FDA Guidance for Industry and EMA guidelines, for dissolution profiles to be considered similar as shown in Figure 4, where more than $85 \%$ of the drug is dissolved within 15 minutes, dissolution profiles may be accepted as similar without further mathematical evaluation of the similarity factor $\mathrm{f} 2$ [37].

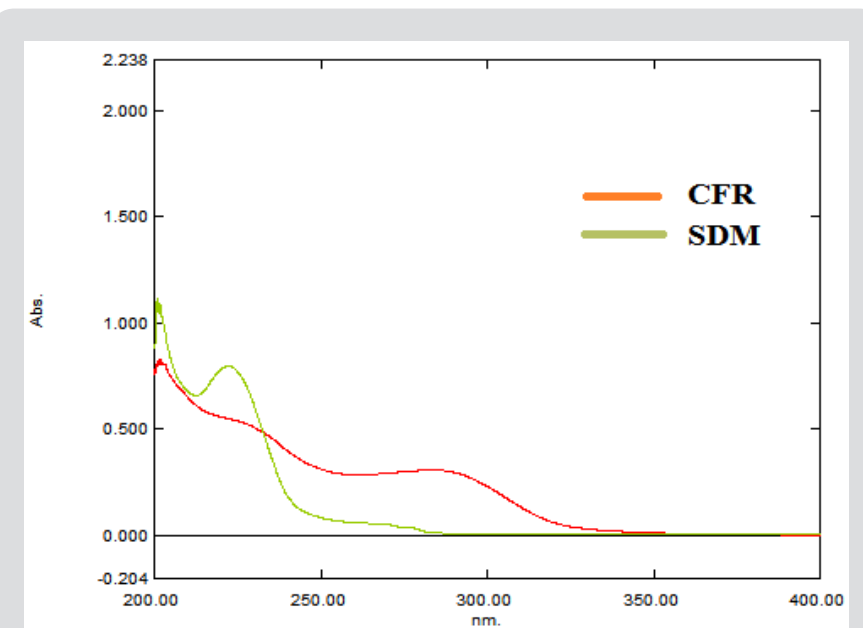

Figure 3: Zero order absorption spectra of $15 \mu \mathrm{g} / \mathrm{mL}$ of each of CFR and SDM using Solvent as blank.

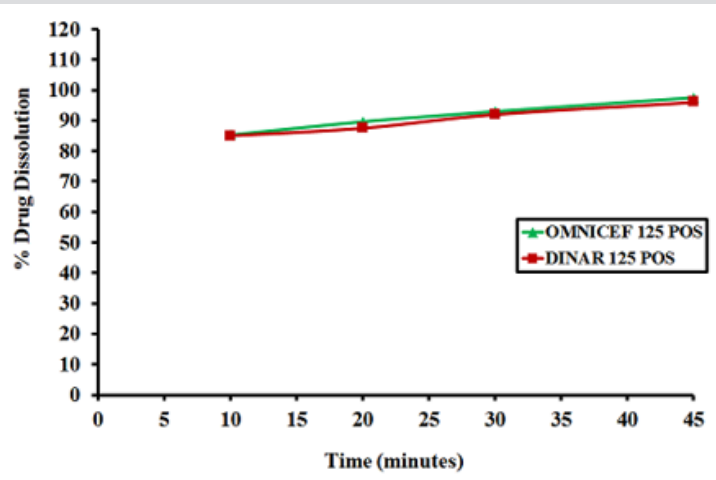

(a)

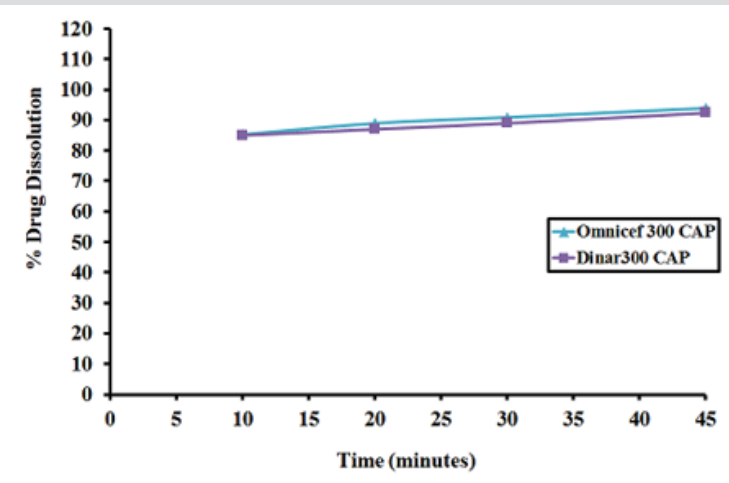

(b)

Figure 4: Dissolution Profile of CFR from (a) Dinar 125 POS, the generic brand and Omnicef 125 POS, the Innovator brand and (b) Dinar $300 \mathrm{CAP}$, the generic brand and Omnicef $300 \mathrm{CAP}$, the Innovator brand.

\section{Method Validation}

The proposed method was validated, in accordance with ICH guidelines [38]. Regarding Linearity and range, LOD and LOQ, Accuracy and recovery, Precision (repeatability and intermediate precision), Robustness, Stability of the analytical solution, Formulation assay, system suitability, specificity.

\section{Linearity and Range}

In order to evaluate the linearity of an assay procedure, a series of standards at different concentrations of the target concentration were prepared. After running each preparation in triplicate, a linear regression analysis was performed on the average peak areas versus the concentrations of the levels studied. The linearity of the proposed methods was obtained over concentration range (50 - 1000 and $5-50 \mu \mathrm{g} / \mathrm{mL}$ ) with coefficient of regression $>0.999$ for CFR and SDM, respectively. The linearity results are shown in Table 1.

\section{Limit of Detection and Quantitation}

The limit of detection (LOD) and limit of quantitation were based on the standard deviation of the response and the slope and can be calculated as $\mathrm{LOD}=3.3 \times \sigma /$ slope and $\mathrm{LOQ}=10 \times \sigma /$ slope, where $\sigma=$ the standard deviation of the response as listed in Table 1. 
Table 1: Regression and validation parameters of the proposed HPLC and UPLC methods for determination of CFR and SDM.

\begin{tabular}{|c|c|c|c|c|}
\hline \multirow{2}{*}{ Parameter } & \multicolumn{2}{|c|}{ HPLC } & \multicolumn{2}{|c|}{ UPLC } \\
\hline & CFR & SDM & CFR & SDM \\
\hline \multicolumn{5}{|l|}{ Linear } \\
\hline Range $(\mu \mathrm{g} / \mathrm{mL})$ & $50-1000$ & $5-50$ & $50-1000$ & $5-50$ \\
\hline Slope & 14369.1024 & 10329.959 & 14354.6637 & 4454.6845 \\
\hline Intercept & 31746.6533 & 678.8789 & 5082.0433 & 245.705 \\
\hline Correlation coefficient & 0.9999 & 0.9998 & 0.9999 & 0.9999 \\
\hline Repeatability & 0.4 & 0.26 & 0.47 & 0.36 \\
\hline $\mathrm{LOD}^{\mathrm{a}}(\mu \mathrm{g} / \mathrm{mL})$ & 6.79 & 0.55 & 6.61 & 0.27 \\
\hline $\mathrm{LOQ}^{\mathrm{a}}(\mu \mathrm{g} / \mathrm{mL})$ & 20.58 & 1.67 & 20.03 & 0.82 \\
\hline
\end{tabular}

a'Limit of detection $(3.3 \times \sigma /$ Slope $)$ and limit of quantitation $(10 \times \sigma /$ Slope $)$.

\section{Accuracy and Recovery}

The recovery was calculated in triplicates of three concentrations $(200,300,400 \mu \mathrm{g} / \mathrm{mL})$ for CFR and $(10,20,40 \mu \mathrm{g} /$ $\mathrm{mL}$ ) for SDM within linearity at all different media comparing the individual peak response with that of the reference solution. The

Table 2: Data of Accuracy and Recovery for CFR and SDM. mean \% recoveries for CFR and SDM were between (98.0 - 102\%). Results are shown in (Table 2). Moreover, accuracy was evaluated by applying the standard addition technique to the samples with good recovery suggesting that there is no involvement from excipients as shown in Table 3.

\begin{tabular}{|c|c|c|c|c|c|c|c|c|c|}
\hline \multirow{3}{*}{$\begin{array}{c}\text { Cefdinir } \\
\text { Standard } \\
\text { Solution } \\
\text { Add }(\mu \mathrm{g} / \\
\mathrm{mL})\end{array}$} & \multirow{3}{*}{$\begin{array}{c}\text { Sodium } \\
\text { Benzoate } \\
\text { Standard } \\
\text { Solution } \\
\text { Add }(\mu \mathrm{g} / \\
\mathrm{mL})\end{array}$} & \multicolumn{4}{|c|}{ HPLC } & \multicolumn{4}{|c|}{ UPLC } \\
\hline & & \multicolumn{2}{|c|}{ CFR } & \multicolumn{2}{|c|}{ SDM } & \multicolumn{2}{|c|}{ CFR } & \multicolumn{2}{|c|}{ SDM } \\
\hline & & $\begin{array}{l}\mu \mathrm{g} / \mathrm{mL} \\
\text { (found) }\end{array}$ & Recovery\% & $\begin{array}{l}\mu \mathrm{g} / \mathrm{mL} \\
\text { (found) }\end{array}$ & Recovery\% & $\begin{array}{l}\mu \mathrm{g} / \mathrm{mL} \\
\text { (found) }\end{array}$ & Recovery\% & $\begin{array}{l}\mu \mathrm{g} / \mathrm{mL} \\
\text { (found) }\end{array}$ & Recovery\% \\
\hline \multirow{3}{*}{200} & \multirow{3}{*}{10} & 199.39 & 99.69 & 10.1 & 101 & 201.36 & 100.68 & 9.96 & 99.65 \\
\hline & & 199.4 & 99.7 & 10.05 & 100.49 & 198.65 & 99.33 & 9.96 & 99.65 \\
\hline & & 199.91 & 99.96 & 10.05 & 100.48 & 198.43 & 99.21 & 10.02 & 100.16 \\
\hline \multirow{3}{*}{300} & \multirow{3}{*}{20} & 304.68 & 101.56 & 19.84 & 99.18 & 304.25 & 101.42 & 20.31 & 101.57 \\
\hline & & 302.87 & 100.96 & 19.81 & 99.07 & 304.53 & 101.51 & 20.25 & 101.23 \\
\hline & & 304.64 & 101.55 & 19.83 & 99.13 & 303.54 & 101.18 & 20.13 & 100.67 \\
\hline \multirow{3}{*}{400} & \multirow{3}{*}{40} & 392.83 & 98.21 & 39.93 & 99.84 & 399.98 & 100 & 39.82 & 99.56 \\
\hline & & 393.31 & 98.33 & 40.02 & 100.06 & 402.57 & 100.64 & 39.93 & 99.83 \\
\hline & & 393.4 & 98.35 & 40.03 & 100.08 & 398.58 & 99.65 & 39.9 & 99.75 \\
\hline $\begin{array}{c}\text { Accuracy } \\
\text { (Mean) } \pm \\
\text { RSD }\end{array}$ & & $99.81 \pm 1.34$ & & $99.92 \pm 0.69$ & & $100.40 \pm 0.88$ & & $100.23 \pm 0.75$ & \\
\hline
\end{tabular}

Table 3: Determination of CFR and SDM in pharmaceutical formulation by the proposed methods and application of standard addition technique.

\begin{tabular}{|c|c|c|c|c|c|c|c|c|c|}
\hline \multirow{3}{*}{$\begin{array}{c}\text { Cefdinir } \\
\text { Standard } \\
\text { Solution } \\
(\mu \mathrm{g} / \mathrm{mL})\end{array}$} & \multirow{3}{*}{$\begin{array}{l}\text { Sodium } \\
\text { Benzoate } \\
\text { Standard } \\
\text { Solution } \\
(\mu \mathrm{g} / \mathrm{mL})\end{array}$} & \multicolumn{4}{|c|}{ HPLC } & \multicolumn{4}{|c|}{ UPLC } \\
\hline & & \multicolumn{2}{|c|}{ CFR } & \multicolumn{2}{|c|}{ SDM } & \multicolumn{2}{|c|}{ CFR } & \multicolumn{2}{|c|}{ SDM } \\
\hline & & $\begin{array}{l}\mu \mathrm{g} / \mathrm{mL} \\
\text { (found) }\end{array}$ & Recovery\% & $\begin{array}{l}\mu \mathrm{g} / \mathrm{mL} \\
\text { (found) }\end{array}$ & Recovery\% & $\begin{array}{l}\mu \mathrm{g} / \mathrm{mL} \\
\text { (found) }\end{array}$ & Recovery\% & $\begin{array}{l}\mu \mathrm{g} / \mathrm{mL} \\
\text { (found) }\end{array}$ & Recovery\% \\
\hline \multirow{3}{*}{50} & \multirow{3}{*}{5} & 49.42 & 98.84 & 4.92 & 98.38 & 49.33 & 98.66 & 4.93 & 98.63 \\
\hline & & 49.64 & 99.28 & 5.01 & 100.18 & 49.52 & 99.04 & 4.99 & 99.7 \\
\hline & & 49.5 & 99 & 5.08 & 101.5 & 49.35 & 98.7 & 5 & 99.96 \\
\hline \multirow{3}{*}{100} & \multirow{3}{*}{10} & 101.61 & 101.61 & 10.06 & 100.56 & 101.38 & 101.38 & 9.92 & 99.19 \\
\hline & & 101.41 & 101.41 & 10.07 & 100.68 & 101.28 & 101.28 & 9.94 & 99.4 \\
\hline & & 101.2 & 101.2 & 10.07 & 100.73 & 101.29 & 101.29 & 9.98 & 99.77 \\
\hline
\end{tabular}




\begin{tabular}{|c|c|c|c|c|c|c|c|c|c|}
\hline \multirow{3}{*}{150} & \multirow{2}{*}{15} & 151.58 & 101.05 & 15.02 & 100.15 & 151.37 & 100.91 & 14.87 & 99.15 \\
\cline { 2 - 10 } & & 151.04 & 100.69 & 15.2 & 101.36 & 151.2 & 100.8 & 14.85 & 99 \\
\cline { 2 - 10 } & 151.16 & 100.77 & 15.07 & 100.44 & 152.9 & 101.94 & 14.88 & 99.22 \\
\hline $\begin{array}{c}\text { Accuracy } \\
\text { (Mean) } \pm \\
\text { RSD }\end{array}$ & & $100.43 \pm 1.07$ & & $100.44 \pm 0.90$ & & $100.44 \pm 1.27$ & & $99.34 \pm 0.42$ & \\
\hline
\end{tabular}

\section{Precision}

Repeatability was proceeded using 6 replicates of the standard solution of the compound being studied $(750 \mu \mathrm{g} / \mathrm{mL})$ for CFR and $(30 \mu \mathrm{g} / \mathrm{mL})$ for SDM in all different media. The system was precise as the relative standard deviation RSD $\leq 2 \%$. High precision Table 4: Ruggedness, Robustness and stability of analytical solution of the proposed method.

\begin{tabular}{|c|c|c|c|c|}
\hline \multirow{2}{*}{ Parameter(\%RSD) } & \multicolumn{2}{|c|}{ HPLC } & \multicolumn{2}{|c|}{ UPLC } \\
\hline & CPR & SDM & CFR & SDM \\
\hline Day to Day & 0.42 & 0.68 & 0.83 & 0.9 \\
\hline Analyst to Analyst & 0.4 & 0.26 & 0.49 & 0.71 \\
\hline Column to Column & 0.51 & 0.88 & 0.78 & 0.72 \\
\hline Flow rate change $( \pm 0.1 \mathrm{~mL} / \mathrm{min})$ & 0.5 & 0.68 & 0.5 & 0.52 \\
\hline pH changes of mobile phase $( \pm 0.2)$ & 0.55 & 0.31 & 0.96 & 0.36 \\
\hline Wave length change $(254 \pm 2.0 \mathrm{~nm})$ & 0.5 & 0.79 & 0.95 & 0.45 \\
\hline Column temperature change $\left(30,25^{\circ} \mathrm{C}\right)$ & 0.52 & 1.47 & 0.91 & 0.51 \\
\hline Fresh Sample & 100.29 & 99.04 & 100.48 & 99.91 \\
\hline Stored Sample in fridge & 99.7 & 98.6 & 99.78 & 99.17 \\
\hline Stored Sample in room temperature & 99.58 & 98.06 & 99.33 & 98.4 \\
\hline
\end{tabular}

\section{Robustness}

For measuring the capability of the method to remain unaffected by small, but deliberate, variations in method's parameters such as: influence of variations of $\mathrm{pH}$ of the mobile phase $( \pm 0.2)$, Flow rate change $( \pm 0.1 \mathrm{~mL} / \mathrm{min})$, wave length change $(254 \pm 2.0 \mathrm{~nm})$ and column temperature change $\left(30,25^{\circ} \mathrm{C}\right)$. Good results were gained as presented in Table 4.

\section{Stability of the Analytical Solution}

The method was proceeded to evaluate the stability assay of the standard solution when it was stored in a fridge and another part of the method was obtained as shown in Table 1. Intermediate precision (ruggedness). Intermediate precision expresses the within-laboratories variation parameters by RSD, evaluation has been tested for different days, different analysts and effect of use of different columns (different lots and/or suppliers). Good results

Table 5: Assay results for the determination of CFR and SDM in their dosage form by the proposed HPLC and UPLC methods.

\begin{tabular}{|c|c|c|c|c|c|}
\hline \multirow{2}{*}{ Pharmaceutical formulation } & \multicolumn{2}{|c|}{ HPLC } & \multicolumn{2}{|c|}{ UPLC } & \multirow{2}{*}{ Limit $\%$} \\
\hline & CFR & SDM & CFR & SDM & \\
\hline \multirow{4}{*}{$\begin{array}{c}\text { OMNICEF } 125 \text { POS } \\
\text { CFR, } 125 \text { mg (claimed) }\end{array}$} & 99.11 & 101.7 & 101.81 & 99.51 & \multirow{9}{*}{$90-110$} \\
\hline & 98.7 & 101.07 & 101.8 & 99.21 & \\
\hline & 98.39 & 100.91 & 101.63 & 99.97 & \\
\hline & 98.09 & 100.62 & 102.56 & 100.75 & \\
\hline \multirow{3}{*}{$\begin{array}{c}\text { SDM,5 mg (claimed) } \\
\text { Mean } \pm \text { RSD }\end{array}$} & 96.82 & 100.35 & 99.76 & 98.92 & \\
\hline & 96.05 & 100.83 & 100.77 & 99.15 & \\
\hline & $97.86 \pm 1.21$ & $100.91 \pm 0.46$ & $101.39 \pm 0.37$ & $99.59 \pm 0.68$ & \\
\hline \multirow{2}{*}{$\begin{array}{c}\text { DINAR } 125 \text { POS } \\
\text { CFR, } 125 \text { mg (claimed) }\end{array}$} & 96.12 & 100.32 & 100.68 & 97.58 & \\
\hline & 97.37 & 100.6 & 99.77 & 98.32 & \\
\hline
\end{tabular}




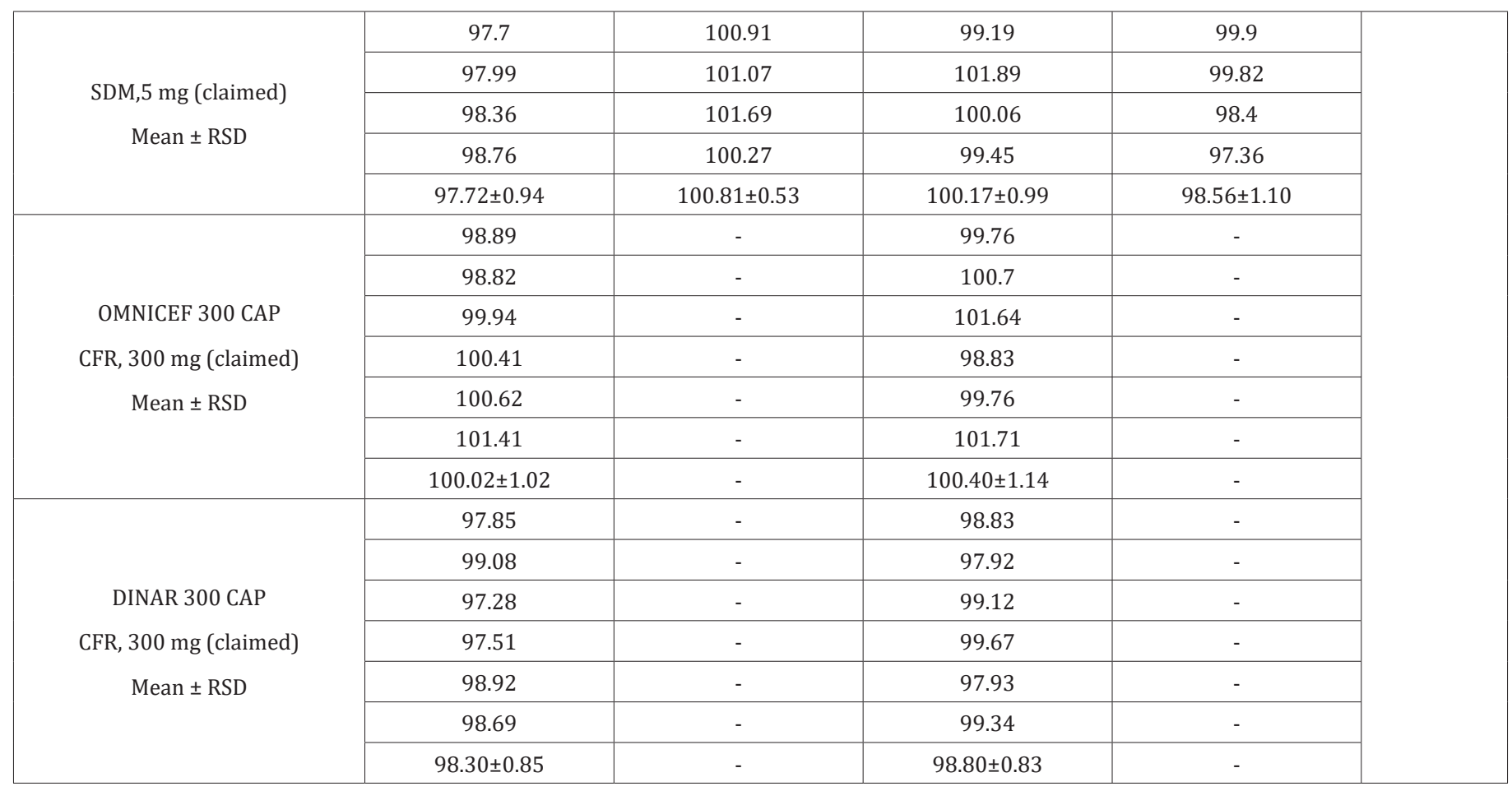

\section{System Suitability}

Tests were based on the concept that chromatographic system, analytical operations and samples to be analyzed constitute an integral system that should be checked by calculating various parameters such as the number of theoretical plates $(\mathrm{N})$, tailing factor (T), resolution (Rs), precision and selectivity $\left(k^{\prime}\right)$ to ensure the performance of the system. All calculated parameters were found within the acceptable limits indicating good selectivity of the method as listed in Table 6.

Table 6: System suitability testing parameters of the developed method.

\begin{tabular}{|c|c|c|c|c|c|}
\hline \multirow{3}{*}{ Item } & \multicolumn{4}{|c|}{ Obtained value } & \multirow{3}{*}{ Reference Values } \\
\hline & \multicolumn{2}{|c|}{ HPLC } & \multicolumn{2}{|c|}{ UPLC } & \\
\hline & CFR & SDM & CFR & SDM & \\
\hline Tailing factor & 1.2 & 1.55 & 1.12 & 1.32 & $\mathrm{~T} \leq 2$ \\
\hline Injection precision & 0.23 & 0.44 & 0.11 & 0.32 & $\mathrm{RSD} \leq 1 \%$ \\
\hline Number of theoretical plates $(\mathrm{N})$ & 4556.78 & 3220.5 & 5543.29 & 4543.77 & $\mathrm{~N}>2000$ \\
\hline Resolution & - & 3.76 & - & 3.25 & Rs $>2$ \\
\hline Retention time $\left(\mathrm{R}_{\mathrm{t}}\right)$ & 0.08 & 0.15 & 0.09 & 0.33 & $\mathrm{RSD} \leq 1 \%$ \\
\hline Selectivity & - & 3.45 & - & 4.1 & $\mathrm{k}^{\prime}>2$ \\
\hline
\end{tabular}

\section{Specificity}

Specificity is the ability to assess unequivocally the analyte in the presence of components that may be expected to be present such as impurities, degradation products and excipient. There must be inarguable data for a method to be specific. Specificity measures only the desired component without interference from other species which might be present; separation is not necessarily required. Also, the standard addition technique was applied by adding known concentration of pure form for both drugs to dosage form and the recovery of the added pure forms were calculated to check the specificity and selectivity of the method. The obtained results shown in Table 3 indicate no matrix interference.

\section{Application of Comparative in vitro Dissolution Study for the Proposed Method}

In vitro dissolution was carried out on two generic products viz., DINAR 125mg/5mL POS and DINAR 300 mg CAP dosage forms selecting dissolution parameters as described by FDA dissolution methods [39]. For comparative studies, the in vitro dissolution of innovator brand e.g., OMNICEF $125 \mathrm{mg} / 5 \mathrm{~mL}$ POS and OMNICEF $300 \mathrm{mg}$ CAP dosage forms were performed at the same conditions and results were compared with those of generic brands. The quantitative release of drug at specified intervals from the product was determined using the validated HPLC and UPLC methods. The dissolution results which are summarized in Table 7 showed that 
the value of RSD \% is less than $10 \%$ at the initial point and less than $5 \%$ for other intervals. Also, the in vitro dissolution profile and the cumulative percentage of generic and innovator products released were plotted against time (Figure $4 \mathrm{a} \& 4 \mathrm{~b}$ ), The dissolution profile of generic brand showed similar behavior to the innovator one.
There was an agreement that the $\mathrm{f} 2$ test is not necessary when the two products each provide at least $85 \%$ dissolution in $15 \mathrm{~min}$. The percentage dissolved for all products was above $85 \%$ of the labeled claimed content from the very first sampling time.

Table 7: Cumulative \% Dissolution profile of CFR in dosage forms using FDA dissolution media after minutes.

\begin{tabular}{|c|c|c|c|c|}
\hline & \multicolumn{4}{|c|}{ Cumulative \% Dissolution data of CFR in dosage forms } \\
\hline Time & Omnicef 125 POS & Dinar 125 POS & Omnicef 300 CAP & Dinar 300 CAP \\
\hline 10 & $85.40 \pm 2.33$ & $85.02 \pm 1.98$ & $85.28 \pm 2.67$ & $85.17 \pm 2.00$ \\
\hline 20 & $89.68 \pm 2.02$ & $87.48 \pm 2.47$ & $89.10 \pm 1.26$ & $86.97 \pm 1.16$ \\
\hline 30 & $92.99 \pm 2.37$ & $92.41 \pm 3.01$ & $90.82 \pm 3.55$ & $89.17 \pm 3.36$ \\
\hline 45 & $97.49 \pm 2.68$ & $95.71 \pm 2.99$ & $93.64 \pm 2.71$ & $92.38 \pm 2.62$ \\
\hline
\end{tabular}

Application of Accelerated and after Reconstitution

\section{Studies}

Accelerated stability studies were conducted at temperature $40 \pm 2{ }^{\circ} \mathrm{C} \&$ relative humidity $75 \pm 5 \%$ for 6 months and after reconstitution studies under $5 \pm 3^{\circ} \mathrm{C}$ in refrigerator for 14 days (Figure $5 \mathrm{a} \& 5 \mathrm{~b}$ ), includes that generic and innovator products attained their physical, chemical and microbiological attributes and no significant change occurred during the study period. The obtained results are shown in Table 8.
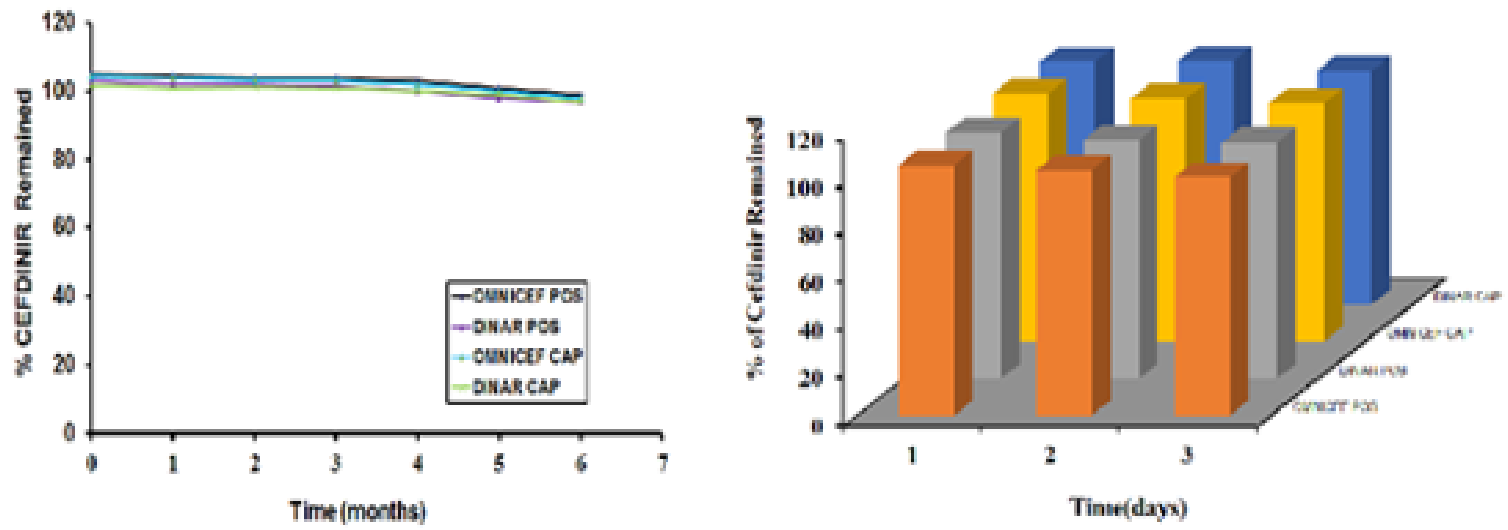

(a)
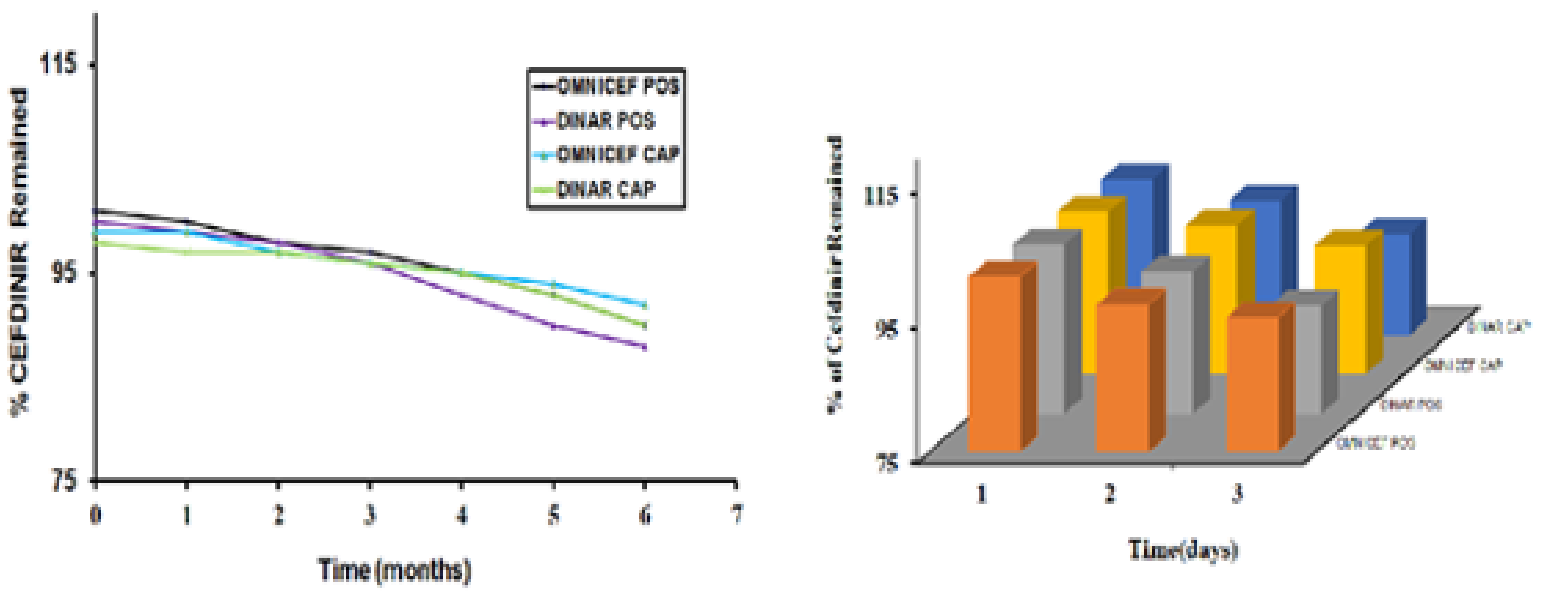

(b)

Figure 5: Cefdinir remained (\%) of (a) assay and dissolution (b) of Omnicef 125 "POS", Dinar 125 "POS" and Omnicef 300 mg "CAP", Dinar $300 \mathrm{mg}$ "CAP" Stored for Six Months at $40^{\circ} \mathrm{C} \& 75 \% \mathrm{RH}$ and 14 days after reconstitution at $5 \pm 3^{\circ} \mathrm{C}$. 
Table 8: Assay and dissolution results for accelerated stability and after reconstitution studies for the determination of CFR in dosage form by the proposed methods.

\begin{tabular}{|c|c|c|c|c|c|c|c|c|c|c|c|}
\hline \multirow{3}{*}{$\begin{array}{l}\text { Pharmaceutical } \\
\text { formulation }\end{array}$} & \multicolumn{10}{|c|}{ Assay Results of CFR in Dosage Form } & \\
\hline & \multicolumn{7}{|c|}{ Accelerated Stability Studies } & \multicolumn{3}{|c|}{ After reconstitution Studies } & \\
\hline & 0 & 1 & 2 & 3 & 4 & 5 & 6 & 0 & 7 & 14 & \\
\hline Omnicef 125 POS & 105 & 104.6 & 104 & 104 & 103 & 101 & 99 & 105 & 103 & 100 & \multirow{2}{*}{$90-120$} \\
\hline Dinar 125 POS & 103 & 102 & 102 & 101.4 & 100 & 98 & 97 & 103 & 100 & 99 & \\
\hline Omnicef 300 CAP & 104.5 & 104 & 103.4 & 103 & 102 & 100 & 98 & 104 & 102 & 100 & \\
\hline \multirow[t]{2}{*}{ Dinar 300 CAP } & 101.7 & 101 & 101.2 & 101 & 100 & 99 & 97 & 101.7 & 100 & 98 & \\
\hline & \multicolumn{10}{|c|}{ Dissolution Results of CFR in dosage form } & \\
\hline \multirow{2}{*}{$\begin{array}{l}\text { Pharmaceutical } \\
\text { Formulation }\end{array}$} & \multicolumn{7}{|c|}{ Accelerated Stability Studies } & \multicolumn{3}{|c|}{ After Reconstitution Studies } & \\
\hline & $\mathbf{0}$ & 1 & 2 & 3 & 4 & 5 & 6 & $\mathbf{0}$ & 7 & 14 & \\
\hline Omnicef 125 POS & 101 & 100 & 98 & 97 & 95 & 93 & 90 & 101 & 97 & 95 & \multirow{3}{*}{ NLT 75} \\
\hline Dinar 125 POS & 100 & 99 & 98 & 96 & 93 & 90 & 88 & 100 & 96 & 91 & \\
\hline Omnicef 300 CAP & 99 & 99 & 97 & 96 & 95 & 94 & 92 & 99 & 97 & 94 & \\
\hline Dinar 300 CAP & 98 & 97 & 97 & 96 & 95 & 93 & 90 & 98 & 95 & 90 & \\
\hline
\end{tabular}

Application of Quality Control and Statistical Tool for Normally Distributed Assay

Data was collected for the last two years of 100 batches of assay for CFR as mentioned in Table 9 by our quality team for monitoring the manufacturing operation for different suppliers. Then, were measured using the Minitab program. Process capability six-pack analysis indicated that the data for the first supplier API corporation (Japan) is statistically capable and more accurate than the second supplier as Cpk is 1.83 (Figure 6a \& 6b), means that it meets 6 sigma levels. Also, in the second supplier covalent lab (India) the process is normally distributed, within the control specification and statistical control as the $\mathrm{Cpk}$ is 1.47 i.e., it meets 4 sigma levels.

Table 9: Application of quality control and statistical tools to monitor Manufacturing Operation.

\begin{tabular}{|c|c|c|}
\hline \multirow{2}{*}{$\begin{array}{c}\text { Parameters } \\
\text { Descriptive Statistic }\end{array}$} & \multicolumn{2}{|c|}{ Values } \\
\hline & API corporation & Covalent lab \\
\hline Mean & 99.047 & 98.819 \\
\hline Standard Error & 0.0682 & 0.102 \\
\hline Median & 99.000 & 98.550 \\
\hline Mode & 99.000 & 98.000 \\
\hline Standard Deviation & 0.682 & 1.023 \\
\hline Variance & 0.465 & 1.047 \\
\hline Kurtosis & 0.82 & -0.01 \\
\hline Skewness & -0.42 & 0.42 \\
\hline Range & 4 & 6 \\
\hline Minimum & 97.000 & 96.000 \\
\hline Maximum & 101.000 & 102.000 \\
\hline Sum & 9904.700 & 9881.900 \\
\hline Count & 100 & 100 \\
\hline Confidence Level (95.0\%) & 0.69 & 1.04 \\
\hline
\end{tabular}




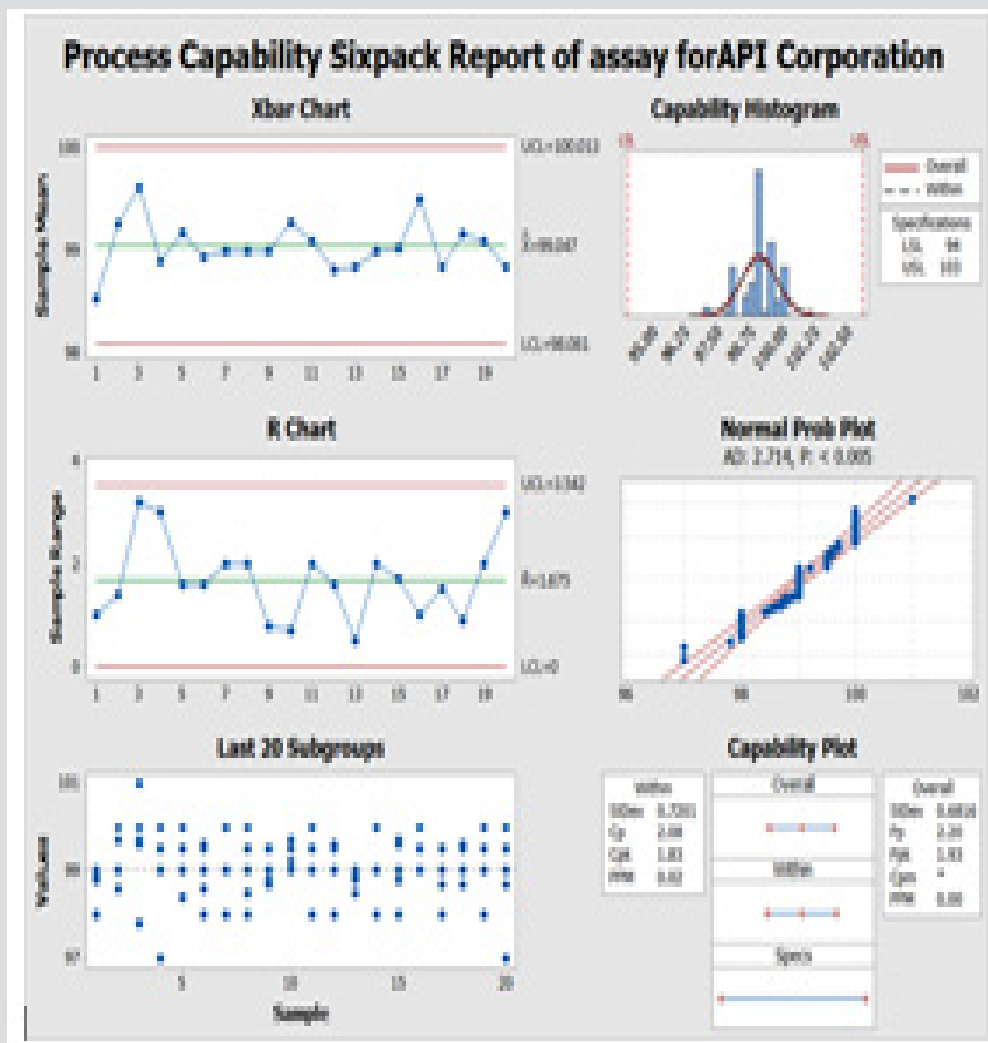

[园]

\section{Process Capability Sixpack Report of assay for covalent lab}

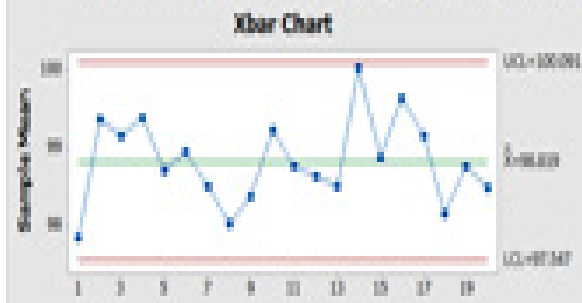

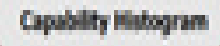
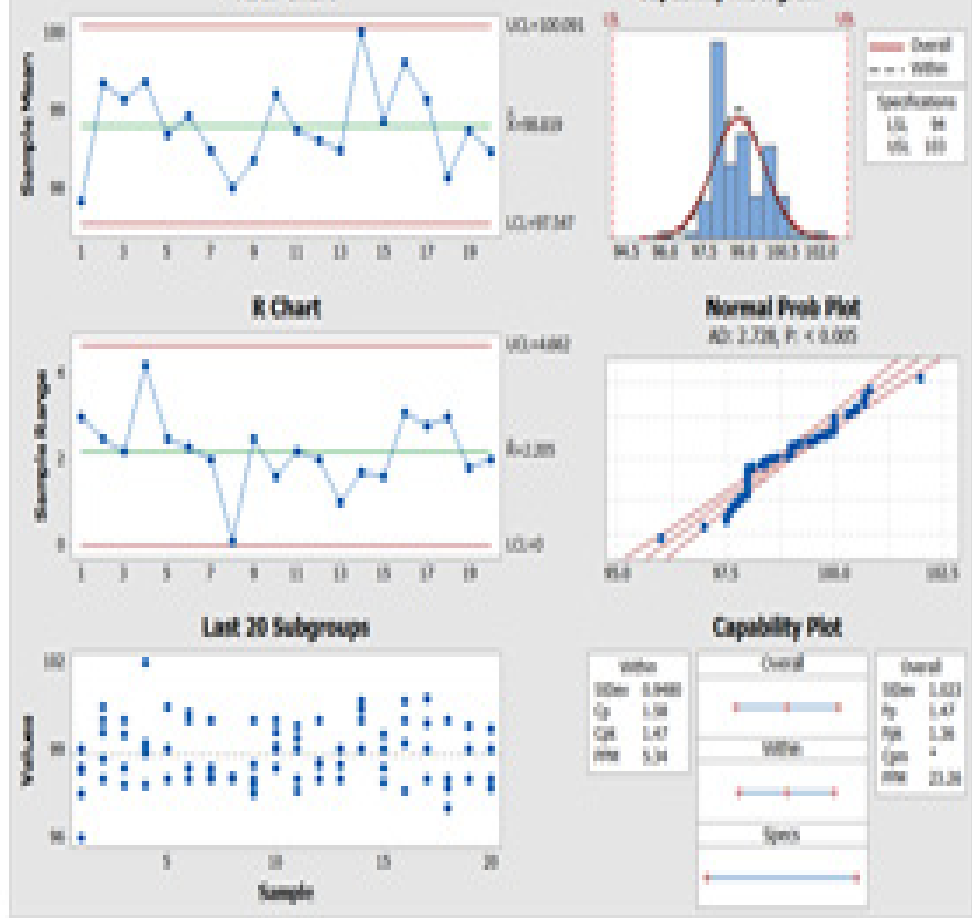

$|6|$

Figure 6: Process Capability Six-pack quality tools for normally distributed assay results of 100 batches of Cefdinir for comparison between two suppliers and (b) covalent lab (India) supplier using Minitab® 17.1.0. 


\section{Conclusion}

Application of lean six sigma and quality tools were performed to detect and eliminate the defect through stages of process and comparison between the two suppliers. So, a specific, accurate and simple HPLC and UPLC methods were developed and properly validated according to the requirements of ICH guidelines for the simultaneous estimation of co-formulated binary mixtures of CFR and SDM in their suspension and capsule dosage forms. Comparative in vitro dissolution studies have been achieved for two generic brands; Dinar 125 POS \& Dinar 300 CAP and hence, it was assumed equivalent to the innovator product of Omnicef 125 POS and Omnicef 300 CAP at FDA dissolution media and the two products were considered identical. Based on the above results, the analytical method is valid and can be used for regular routine analysis and stability study.

\section{References}

1. García Alcaraz J, Alor Hernández G, Sánchez Ramírez C, Jiménez Macías E, et al. (2018) Mediating Role of the Six Sigma Implementation Strategy and Investment in Human Resources in Economic Success and Sustainability. Sustainability 10(6): 1828.

2. Description and Clinical Pharmacology for Cefdinir Drug (2006) U S Food and Drug Administration.

3. Description of sodium benzoate (2017) US Food and Drug Administration

4. Rockville (2018) USP 41 NF 36: United States pharmacopeia and National formulary. United States Pharmacopeial Convention, Supply2.

5. Akl MA, Ahmed MA, Ramadan A (2013) Development and Validation of a Liquid Chromatographic Method for the Determination of Cefdinir Residues on Manufacturing Equipment Surfaces. J Chromat Separation Techniq 4: 177.

6. Al Badr AA, Alasseiri FA (2014) Cefdinir In Profiles of Drug Substances, Excipients and Related Methodology. Academic Press 39: 41-112.

7. Chen ZJ, Zhang J, Yu JC, Cao GY, Wu XJ, et al. (2006) Selective method for the determination of cefdinir in human plasma using liquid chromatography electrospray ionization tandam mass spectrometry. Journal of Chromatography B 834(1-2): 163-169.

8. Kumudhavalli MV, Chandira RM, Jayakar B, Goswami S (2009) RP-HPLC determination of cefdinir in bulk drug and solid dosage form. Journal of Pharmacy Research 2(6): 1141-1143.

9. Li J, Wang L, Chen Z, Xie R, Li Y, et al. (2012) Development and validation of a rapid HPLC method for the determination of cefdinir in beagle dog plasma integrated with an automatic on-line solid-phase extraction following protein precipitation in the 96-well plate format. Journal of Chromatography B 895-896: 83-88.

10. Narala SR, Saraswathi K (2011) RP-HPLC methods for the determination of cephalosporins (Cefditoren Pivoxil and Cefdinir) in pharmaceutical dosage forms. Journal of Pharmaceutical Sciences and Research 3(1): 1002-1004.

11. Nirupa G, Tripathi UM (2015) Analytical Method Development and Validation on Liquid Chromatography for Determination of the Drug Cefdinir by Using Tinidazole as an Internal Standard in Bulk and Pharmaceutical Dosage Forms. ACSj 5(4): 285-296.

12. Shahed GM, Ullah MA, Maruf AA, Ahmed MU, Islam MS, et al. (2012) A Simple RP-HPLC Method for the Determination of Cefdinir in Human Serum: Validation and Application in a Pharmacokinetic Study with Healthy Bangladeshi Male Volunteers. Dhaka University Journal of Pharmaceutical Sciences. 10(2): 109-116.
13. Krishnaphanisri ponnekanti, Raja Sundararajan (2018) Development and validation of new rp-uplc method for the determination of cefdinir in bulk and dosage form. Int J Pharm Pharm Sci 10(1): 178-184.

14. Jain R, Dwivedi A, Mishra R (2008) Voltammetric behavior of cefdinir in solubilized system. Journal of colloid and interface science 318(2): 296301.

15. Jain R, Radhapyari K, Jadon N (2007) Electrochemical evaluation and determination of cefdinir in dosage form and biological fluid at mercury electrode. Journal of the Electrochemical Society 154(11): 199-204.

16. Abdel Aziz O, Farouk M, Nagi R, Abdel-Fattah L (2014) Simple Spectrophotometric and HPTLC-Densitometric Methods for Determination of Cefdinir in Bulk Powder and Pharmaceuticals, and in Presence of its Hydrolytic Degradation Products. Journal of Applied Pharmaceutical Science 4(7): 129-136.

17. Gouda AA, Hashem H, Hassan W (2012) Spectophotometric methods for determination of cefdinir in pharmaceutical formulations via derivatization with 1, 2-naphthoquinone-4-sulfonate and 4-chloro-7nitrobenzo-2-oxa-1, 3-diazole. Drug testing and analysis 4(12): 9911000 .

18. Shah PB, Pundarikakshudu K (2004) UV spectroscopic and colorimetric methods for the estimation of cefdinir in capsule dosage forms. Indian journal of pharmaceutical sciences 66: 665- 667.

19. Abou-Taleb NH, El-Wasseef DR, El-Sherbiny DT, El-Ashry SM (2016) Optimizing the spectrofluorimetric determination of cefdinir through a Taguchi experimental design approach. Luminescence 31(3): 856-864.

20. BAȘ E, ÖZDEMIR S, ÇAĞLAYAN MG, Palabiyik IM, Onur F (2013) First derivative spectrophotometry determination of cefixime and cefdinir in pharmaceutical preparations. Turkish Journal of Pharmaceutical Sciences. Turk J Pharm Sci 10(3): 321-328.

21. El Sheikh R, Amin AS, Gouda AA, Zahran D (2017) Validated spectrophotometric methods for determination of cefdinir in pure and dosage forms through charge transfer complexation using alizarin derivatives. International Journal of Research in Pharmacy and Pharmaceutical Sciences 2(6): 11-18.

22. Hassouna MEM, Mohamed MA (2018) Comparative In-Vitro Dissolution Studies for Determination of Cefixime in an Innovator Product of Suprax Powder for Oral Suspension Dosage Form Using RP-HPLC Method. Glob J Oto 14(3): 555886.

23. Mohamed MA, Ali AH, Abdelfatah AM, Ahmed MO (2018) Validation and Comparative In-vitro Dissolution Studies of Cefaclor in Their Powder for Oral Suspension Dosage Forms. Analytical Chemistry Letters 8(1): 88103.

24. (2017) British Pharmacopoeia.ationary Office 2017. Medicines and Healthcare Products Regulatory Agency; London.

25. Așçı B, Dinç Zor Ș, Aksu Dönmez Ö (2016) Development and validation of HPLC method for the simultaneous determination of five food additives and caffeine in soft drinks; International Journal of Analytical Chemistry, p. 1-8.

26. Gören AC, Bilsel G, Şimşek A, Bilsel M, Akçadağ F, et al. (2015) HPLC and LC-MS/MS methods for determination of sodium benzoate and potassium sorbate in food and beverages: Performances of local accredited laboratories via proficiency tests in Turkey. Food chemistry 175: 273-279.

27. Hassouna, MEM, Abdelrahman MM, Mohamed MA (2017) Validation of a Novel and Sensitive RP-HPLC Method for Simultaneous Determination of Cefixime Trihydrate and Sodium Benzoate in Powder for Oral Suspension Dosage Form; J Forensic Sci \& Criminal Inves 2(4): 555600.

28. Kumar N, Sangeetha D, Sunil Reddy P, Prakash L (2011) A validated stability-indicating RP-UPLC method for simultaneous determination of desloratadine and sodium benzoate in oral liquid pharmaceutical formulations. Scientia pharmaceutica 80(1): 153-166. 
29. Merey HA, Ramadan NK, Diab SS, Moustafa AA (2018) Validated UPLC method for the determination of guaiphenesin, oxeladin citrate, diphenhydramine, and sodium benzoate in their quaternary mixture used in treatment of cough, in the presence of guaiphenesin-related substance (guaiacol). Chemical Papers 72(9): 2247-2254.

30. Popović G, Čakar M, Agbaba D (2007) Simultaneous determination of loratadine and preservatives in syrups by thin-layer chromatography. Acta Chromatogr 19: 161-169.

31. Somya KV, Ravishankar K, Basha DP, Kiranmayi GVN (2011) Estimation of caffeine and sodiun benzoate in caffeine and sodium benzoate injection by isoabsorption method (isobestic method). Int J Pharm Chem Biol Sci 1(1): 26-31.

32. Hassouna MEM, Abdelrahman MM, Mohamed MA (2017) Novel Spectrophotometric Methods for Simultaneous Determination of Cefixime trihydrate and Sodium benzoate in Powder for Oral Suspension Dosage form. Glob J Oto 12(4): 555841.

33. Kompany Zareh M, Mirzaei S (2004) Spectrophotometric resolution of ternary mixtures of pseudoephedrine hydrochloride, dextromethorphan

\section{ISSN: 2574-1241}

DOI: 10.26717/BJSTR.2019.16.002901

Mohamed EM Hassouna. Biomed J Sci \& Tech Res

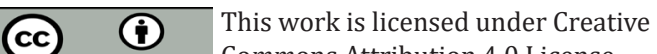

Submission Link: https://biomedres.us/submit-manuscript.php hydrobromide, and sodium benzoate in syrups using wavelength selection by net analyte signals calculated with hybrid linear analysis. Analytica chimica acta 526(1): 83-94.

34. (2003) ICH Guidelines. Stability testing of new drug substances and products. Q1A (R2) 4: 1-24.

35. Brown CK, Chokshi HP, Nickerson B, Reed RA, Rohrs BR, et al. (2004) Dissolution testing of poorly soluble compounds. Pharm Tech 28: 56-65.

36. Mashru RC, Saikumar SV (2010) Development and validation of spectroscopic methods for simultaneous estimation and dissolution of ofloxacin and ornidazole in tablet dosage forms. Ecl Quím São Paulo 35(3): 123-132.

37. (2006) EMEA, The European Agency for the Evaluation of Medicinal Products.

38. (2005) ICH guidelines, Q2 (R1): Validation of Analytical Procedures: Text and Methodology. International Conference on Harmonization IFPMA, Geneva, Switzerland.

39. (2007) Dissolution Methods (2007) US. Food and Drug Administration.

$\begin{array}{ll}\text { BIOMEDICAL } & \text { Assets of Publishing with us } \\ \text { RESEARCHES } & \text { - Global archiving of articles } \\ & \text { - Immediate, unrestricted online access } \\ & \text { - Rigorous Peer Review Process } \\ & \text { - Authors Retain Copyrights }\end{array}$

